\title{
PENGARUH SUBSTITUSI SARI KACANG KOMAK (LABLAB PURPUREUS (L.) SWEET) DAN SUSU SKIM TERHADAP SIFAT ORGANOLEPTIK, NILAI PH, DAN TOTAL BAKTERI ASAM LAKTAT YOGHURT KACANG KOMAK
}

\author{
Effect of Substitution of Lablab Bean Juice purpureus (L.) sweet and Skim Milk Substitution \\ Organoleptic Characteristic, pH Value, and Total Lactic Acid Bacteria of Lablab Yoghurt
}

\author{
Astrid Widiastuti ${ }^{1}$, Judiono ${ }^{2}$ \\ ${ }^{1}$ Program Studi Gizi, Universitas Airlangga Surabaya \\ ${ }^{2}$ Ketua Program Studi Program Studi DIII Gizi Jurusan Gizi, Politeknik Kesehatan Kemenkes Bandung \\ Email: astridwidia@gmail.com
}

\begin{abstract}
ABSTRAK
Kacang komak berpotensi sebagai pangan alternatif pengganti kedelai dengan kandungan gizi yang tidak jauh berbeda, tetapi kadar lemak yang jauh lebih rendah. Yoghurt kacang komak adalah produk susu fermentasi dengan bakteri Lactobacillus bulgaricus dan Streptococcus thermophillus, sehingga laktosa diubah menjadi asam laktat dan diperoleh keasaman, bau, dan rasa yang khas. Tujuan penelitian adalah mengetahui pengaruh pemberian substitusi sari kacang komak dan susu skim terhadap sifat organoleptik, nilai $\mathrm{pH}$, dan total bakteri asam laktat (BAL). Desain penelitian yaitu rancangan acak lengkap dengan sampel sebanyak 30 panelis. Penelitian dilakukan sebanyak 3 perlakuan dengan 2 pengulangan. Data yang dikumpulkan adalah total BAL dan nilai $\mathrm{pH}$. Uji sifat organoleptik menggunakan uji mutu hedonik dengan 1 pengulangan. Nilai $\mathrm{pH}$ diukur menggunakan $\mathrm{pH}$ meter elektronik. Total BAL diukur menggunakan media Man Rogosa and Sharpe (MRS). Kadar asam laktat diuji menggunakan uji keasaman. Perlakuan substitusi sari kacang komak dilakukan dengan $92 \%$, 95\%, dan 96,5\%, dengan susu skim 8\%, 5\% dan 3,5\%. Data dianalisis dengan Anova, Kruskal Wallis, Duncan Multi Range tingkat kemaknaan p $<0,05$. Hasil menunjukkan bahwa sifat organoleptik substitusi 92:8 lebih mendekati kualitas yoghurt yang diharapkan dengan nilai pH terendah, serta nilai pH tertinggi terdapat pada substitusi 96,5:3,5. Total BAL dan kadar asam laktat menunjukkan substitusi 92:8 memiliki nilai tertinggi dan substitusi 96,5:3,5 nilai terendah. Hasil mikroskopis pewarnaan Gram terdapat bakteri Streptococcus thermopillus, dan Lactobacillus bulgaricus pada yoghurt kacang komak. Kacang komak berpotensi sebagai bahan utama pembuatan yoghurt.
\end{abstract}

Kata kunci : bakteri asam laktat, organoleptik, pH, yoghurt kacang komak

\begin{abstract}
Lablab bean has potential as alternative food subtitute of soybean Lablab Bean has nutrients content which is not much different, but fat content is much lower than soybean. Yogurt is milk fermented by the lactic acid bacteria Streptococcus thermophilus and Lactobacillus bulgaricus that tranform milk sugar (lactose) into lactic acid to obtain acidity, smell, and specific flavor. The aim of this research was to study the effect of substitution of lablab bean milk and skim milk to organoleptic properties, $\mathrm{pH}$ value, and the total of lactic acid bacteria (LAB). The Experimental design was applied using completely randomized design with 30 untrained panelists. The research conducted in three treatments with two repetitions. The data collected are total $L A B$ and $p H$ value. The organoleptic properties test used was hedonic quality test with one repitition. The $\mathrm{pH}$ value was measured using an electronic $\mathrm{pH}$ meter. The total of LAB was measured using Man Rogosa and Sharpe (MRS) media. The level of lactic acid was measured using acidity test. The treatment applied was the effect of substitution of lablab bean milk 92\%, 95\%, and 96,5\%, and skim milk 8\%, 5\%, and 3,5\%. Data were analyzed with Anova, Kruskal Wallis, Duncan Multi Range with significance level $p<0,05$. The result showed that organoleptic properties of substituion 92:8 is closer to the expected quality of yoghurt with the lowest pH value, and the highest $\mathrm{pH}$ value is substitution 96,5:3,5. The measurement results of the total LAB and lactic acid levels showed the substitution 92:8 has the highest value and the substitution of 96,5:3,5 has the lowest value. The result of
\end{abstract}


Microscopic on Gram staining showed that Streptococcus thermopillus and Lactobacillus bulgaricus bacteria were found in lablab beans yoghurt. This result indicates that the lablab bean can be potentially used as the main material to make yoghurt.

Keywords: lactic acid bacteria, organoleptic, $\mathrm{pH}$, lablab bean yoghurt

\section{PENDAHULUAN}

Dewasa ini terdapat kecenderungan selektivitas konsumen mengkonsumsi suatu makanan atau minuman, tidak hanya dinilai dari segi kandungan zat gizi serta lezat atau tidaknya suatu produk, tetapi juga mempertimbangkan pengaruh makanan tersebut bagi kesehatan tubuh. Pengolahan bahan pangan dengan proses fermentasi oleh mikroba tertentu mampu meningkatkan nilai gizi yang ada pada produk fermentasi (Bangun, 2009). Peranan mikroorganisme dalam proses pengolahan produk pangan harus ditingkatkan untuk antisipasi kompetisi global saat ini dan di masa depan sejalan berkembangnya teknologi pangan, untuk pemenuhan kebutuhan pangan masyarakat Indonesia. Pengolahan bahan pangan dengan proses fermentasi merupakan metode pengawetan yang bergantung pada produksi mikroorganisme tertentu. Proses ini menyebabkan perubahanperubahan kimia dan fisik yang mengubah rupa, bentuk (body) dan flavor bahan pangan aslinya. Perubahan-perubahan ini dapat memperbaiki nilai gizi dari produk dan umumnya menghambat pertumbuhan mikroorganisme yang tidak diinginkan. Salah satu produk hasil fermentasi adalah susu terfermentasi.

Yoghurt adalah produk susu yang difermentasi dengan bakteri campuran bakteri Lactobacillus bulgaricus dan Streptococcus thermophillus, dan atau bakteri asam laktat yang sesuai, dengan atau tanpa penambahan bahan pangan lain dan bahan tambahan pangan yang diizinkan sampai diperoleh keasaman, bau, dan rasa yang khas (Surajudin, et al., 2008).

Pangan lokal kacang komak dapat diolah dengan menggunakan teknologi fermentasi. Kacang komak merupakan kacang-kacangan yang memiliki potensi ekonomi yang cukup tinggi. Kacang komak berpotensi sebagai pangan alternatif pengganti kedelai dengan kandungan gizi yang tidak jauh berbeda. Saat ini kacang komak banyak ditanam di daerah Jawa Timur dan
Nusa Tenggara Barat, dengan jumlah produksi bisa mencapai 1,5 ton per hektar (Suharjanto, 2010). Kandungan protein biji kacang komak berkisar antara 21-29\% sedangkan kandungan protein kacang kedelai sebesar $40 \mathrm{~g}$. Kandungan lemak pada kacang komak lebih rendah, yaitu 1,2 g dibandingkan dengan kacang kedelai sebesar $16,7 \mathrm{~g}$, sehingga sangat cocok untuk orang-orang yang diet terhadap makanan kandungan lemak tinggi (Suharjanto, 2010). Menurut penelitian Hartoyo, et al. (2011) menunjukkan bahwa ransum ekstrak protein kacang komak terbukti mampu menurunkan kadar glukosa darah pada tikus diabetes. Selain itu, penelitian ini menunjukkan bahwa protein kacang komak mampu menurunkan kadar kolesterol total, trigliserida dan LDL kolesterol serum tikus percobaan. Susunan asam amino kacang komak mendekati pola protein kedelai, yaitu kurang mengandung asam amino yang mengandung belerang (metionin dan sistein), tetapi kaya akan asam amino lysine, sehingga dapat dipakai sebagai suplemen dalam pembuatan bahan makanan campuran yang tersusun dari kacangkacangan yang umumnya kekurangan lysine (Ratnaningtyas, 2003).

Susu skim adalah bagian susu yang tertinggal setelah krim diambil sebagian atau seluruhnya (Adriani, et al., 2008). Penambahan susu skim dalam pembuatan yoghurt mampu memberikan konsistensi dan bentuk yang lebih baik serta meningkatkan nilai gizi yoghurt (Ariyani, 2013).

Yoghurt dibuat melalui proses fermentasi menggunakan bakteri Lactobacillus bulgaricus dan Streptococcus thermophillus. Proses fermentasi tersebut mampu mencegah pertumbuhan mikroba patogen dalam produk yang dihasilkannya, meningkatkan nilai gizi lebih tinggi dibandingkan dengan bahan asalnya dan dapat memecah laktosa susu menjadi senyawa lebih sederhana, sehingga mudah dicerna (Adriani, et al., 2008). Faktor yang berperan penting dalam menghasilkan flavor serta berpengaruh terhadap aroma yoghurt adalah kultur 
starter. Aroma yoghurt disebabkan terbentuknya senyawa-senyawa lain selain asam laktat yaitu asetaldehida, diasetil dan asam asetat (Hartoto, 2003). Berdasarkan uraian tersebut, tujuan penelitian adalah mengetahui pengaruh substitusi sari kacang komak dan susu skim terhadap sifat organoleptik, nilai $\mathrm{pH}$, dan total bakteri asam laktat.

\section{METODE PENELITIAN}

\section{Bahan dan Alat}

Bahan baku yang digunakan dalam penelitian ini adalah kacang komak, susu skim, stater Lactobacillus bulgaricus dan Streptococcus thermophillus (1:1), gula pasir, soda kue, daun pandan, dan jahe. Bahan kimia yang digunakan untuk analisis adalah media MRS broth, larutan $\mathrm{NaOH} 0,1 \mathrm{~N}$, larutan $\mathrm{H}_{2} \mathrm{SO}_{4}$, dan indikator PP.

Alat-alat yang digunakan adalah termometer, blender, timbangan, gelas ukur, panci, kompor, pengaduk kayu, baskom plastik, kain batis, inkubator, gelas kimia, autoclave, cawan petri, erlenmeyer, buret, penangas air, dan formulir uji organoleptik.

\section{Prosedur Kerja}

Pembuatan Sari Kacang Komak

Pembuatan sari kacang komak dimulai dengan penyortiran kacang komak dengan cara merendam kacang komak dalam air dan tunggu beberapa saat. Biji yang mengapung diatas air merupakan biji yang jelek/rusak, sehingga harus dibuang. Kemudian rendam kacang komak dengan air dingin yang ditambah soda kue $0,5 \%$ selama $6-12$ jam. Selesai perendaman, dibilas dan dibuang airnya kemudian dicuci dengan air bersih sambil diremas-remas dengan tangan. Kacang komak selanjutnya direbus dengan jahe dan daun pandan selama 30 menit. Setelah selesai perebusan, kacang didiamkan dengan airnya selama 30 menit. Lalu buang airnya dan ganti dengan air bersih dan lakukan pengupasan kulit ari dengan cara kacang dalam keadaan terendam diremas-remas sambil ditekan hingga kulit arinya mengelupas. Masukkan kacang komak yang sudah selesai dikupas kedalam blender dan beri air panas dengan perbandingan
1:9, kemudian disaring menggunakan kain batis. Sari kacang komak kemudian dimasak pada suhu $90^{\circ} \mathrm{C}$ tidak sampai mendidih selama 10 menit.

Pembuatan Yoghurt Kacang Komak

Imbangan substitusi setiap formula yang didapatkan diolah menggunakan aplikasi Dx8 Trial dengan memasukkan kadar imbangan terendah dan tertinggi pada penelitian terdahulu sehingga mampu menghasilkan imbangan yang terbaik untuk dapat diujikan. Tiga formula substitusi sari kacang komak dan susu skim yang didapatkan ialah 92\%:8\%, 95\%:5\%, dan 96,5\%:3,5\%. Selain itu, setiap formula dilakukan penambahan gula pasir sebanyak $8 \%$. Selanjutnya dilakukan pasteurisasi pada suhu $70^{\circ} \mathrm{C}$ selama 15 menit. Selesai pasteurisasi dinginkan hingga suhu $40^{\circ} \mathrm{C}$. Kemudian siapkan stater berupa biakan Lactobacillus bulgaricus dan Streptococcus thermophilus 5\%. Campurkan stater dengan sari kacang komak yang sudang didinginkan, kemudian simpan dalam inkubator dalam suhu $37^{\circ} \mathrm{C}$ selama 16-18 jam. Inkubasi dirasa cukup apabila sudah terlihat pengentalan, $\mathrm{pH} 3,8-4,5$ dan membentuk yoghurt (Winarti, et al., 2010) dengan modifikasi oleh penulis.

\section{Pengujian Sifat Organoleptik}

Pengujian terhadap sifat organoleptik meliputi rasa, aroma, warna dan konsistensi yoghurt kacang komak yang dilakukan oleh 30 orang panelis tidak terlatih dari mahasiswa Jurusan Gizi Poltekkes Bandung tingkat 1, 2, dan 3. Kriteria panelis yang diperbolehkan untuk melakukan uji organoletik, ialah mempunyai kepekaan yang normal (tidak buta warna), panelis tidak dalam keadaan lapar, serta panelis tidak dalam keadaan merokok, sakit atau tidak dalam kondisi yang dapat mengganggu kepekaan panelis. Penilaian organoleptik yang dilakukan adalah metode uji mutu hedonik. Kisaran skor yang diberikan 1 sampai 7. Skor untuk rasa, yaitu 1 untuk kategori tidak asam, skor 2 untuk kategori agak tidak asam, skor 3 untuk kategori biasa saja, skor 4 untuk kategori agak asam, skor 5 untuk kategori asam, skor 6 untuk kategori sangat asam, dan skor 7 untuk kategori amat sangat asam. Untuk warna, yaitu 1 untuk kategori abu tua, skor 
2 untuk kategori abu, skor 3 untuk kategori abu muda, skor 4 untuk kategori putih keabuan, skor 5 untuk kategori putih gading, skor 6 untuk kategori putih, dan skor 7 untuk kategori putih bersih. Untuk aroma langu, yaitu 1 untuk kategori sangat kuat, skor 2 untuk kategori kuat, skor 3 untuk kategori agak kuat, skor 4 untuk kategori biasa saja (tidak berbau langu), skor 5 untuk kategori agak ringan, skor 6 untuk kategori ringan, dan skor 7 untuk kategori sangat ringan. Untuk konsistensi, yaitu 1 untuk kategori tidak kental, skor 2 untuk kategori agak tidak kental, skor 3 untuk kategori biasa saja, skor 4 untuk kategori agak kental, skor 5 untuk kategori kental, skor 6 untuk kategori sangat kental, dan skor 7 untuk kategori amat sangat kental. Penelitian ini sudah mendapatkan persetujuan dari Komisi Etik Penelitian Kesehatan Politeknik Kesehatan Kementerian Kesehatan Bandung (KEPK-PKKB).

\section{Pengujian Nilai pH}

Pengujian $\mathrm{pH}$ dilakukan dengan menggunakan $\mathrm{pH}$ meter elektronik. Sebelum $\mathrm{pH}$ meter elektronik digunakan dilakukan kalibrasi dengan ujung katoda dicelupkan ke dalam larutan buffer $\mathrm{pH}$ 7. Kemudian ujung katoda indikator dicuci menggunakan akuades, lalu dikeringkan menggunakan tissue. Selanjutnya katoda dicelupkan dalam sampel yoghurt. Hasil pengukuran dibaca pada $\mathrm{pH}$ meter (Kumalasari, et al., 2013).

\section{Pengujian Total Bakteri Asam Laktat}

Perhitungan total BAL dilakukan dengan menggunakan metode hitungan cawan (Total Plate Count). Total BAL yang tumbuh dihitung pada media biakan Man Rogosa and Sharpe (MRS). Pengenceran dilakukan dari $10^{-1}-10^{-9}$, pada pengenceran pertama sebanyak $1 \mathrm{~mL}$ sampel diencerkan kedalam $9 \mathrm{~mL}$ akuades steril, pengenceran kedua dilakukan dengan 1 $\mathrm{mL}$ yang sudah diencerkan pada pengenceran pertama dimasukkan kedalam $9 \mathrm{~mL}$ akuades steril, pengenceran ketiga dan seterusnya. Pengenceran yang dikehendaki diambil sebanyak $1 \mathrm{~mL}$ dan ditanam kedalam cawan petri kemudian ditambahkan medium dan campurkan dengan cara menggoyangkan cawan petri mengikuti angka 8 .
Cawan petri yang telah memadat diinkubasi pada suhu $41^{\circ} \mathrm{C}$ selama 2 hari (Jannah, et al., 2014).

\section{Pengujian Keasaman (Asam Laktat)}

Pengujian keasaman (asam laktat) menggunakan metode titrasi. Pengujian tersebut dilakukan dengan cara sampel yoghurt diambil sebanyak $20 \mathrm{ml}$, dimasukkan kedalam erlenmeyer lalu diteteskan indikator PP (fenolftalin) 1\% sebanyak 2 tetes kedalam erlenmeyer lalu dititrasi dengan larutan $\mathrm{NaOH} \mathrm{0,1} \mathrm{N} \mathrm{hingga} \mathrm{berwarna}$ merah muda konstan (Kumalasari, et al., 2013)

\section{HASIL DAN PEMBAHASAN}

\section{Sifat Organoleptik Yoghurt Kacang Komak}

Data hasil uji organoleptik terlebih dahulu diuji normalitasnya menggunakan Kolmogorov Smirnov dan didapatkan bahwa dari semua sifat organoleptik menunjukkan data tidak terdistribusi normal dengan nilai $\mathrm{p}$ yaitu $0,000(\mathrm{p}<0,05)$. Oleh karena itu semua data organoleptik diolah selanjutnya menggunakan uji statistik Kruskal Wallis. Penilaian panelis terhadap rasa, aroma, warna dan konsistensi dapat dilihat dalam gambar 1. Berdasarkan penelitian Nizori, et al. (2008) pada pembuatan yoghurt sinbiotik, menunjukkan bahwa citarasa asam merupakan salah satu rasa yang menjadi ciri khas yoghurt, selain itu proses ini menghasilkan sifat sensori dan tekstur yang lebih baik, tetapi belum mampu menutupi aroma langu kacang pada yoghurt.

Pengujian warna yang diharapkan pada yoghurt kacang komak ialah berwarna putih gading. Hasil rata-rata penilaian uji organoleptik dari 30 panelis menyatakan bahwa substitusi 92:8 memperoleh nilai paling tinggi yaitu 4,93 yang artinya mendekati warna putih gading. Hasil uji Kruskal Wallis didapat bahwa nilai $\mathrm{p}=0,284(\mathrm{p}>0,05)$, bahwa tidak ada pengaruh substitusi sari kacang komak dan susu skim bubuk terhadap warna yoghurt kacang komak. Salah satu yang dapat menyebabkan perubahan warna bahan makanan ialah pigmen. Pigmen flavonoid dalam kacang komak memberikan warna putih kekuningan pada sari kacang komak (Winarno, 2002). Hal ini diiduga merupakan akibat dari 


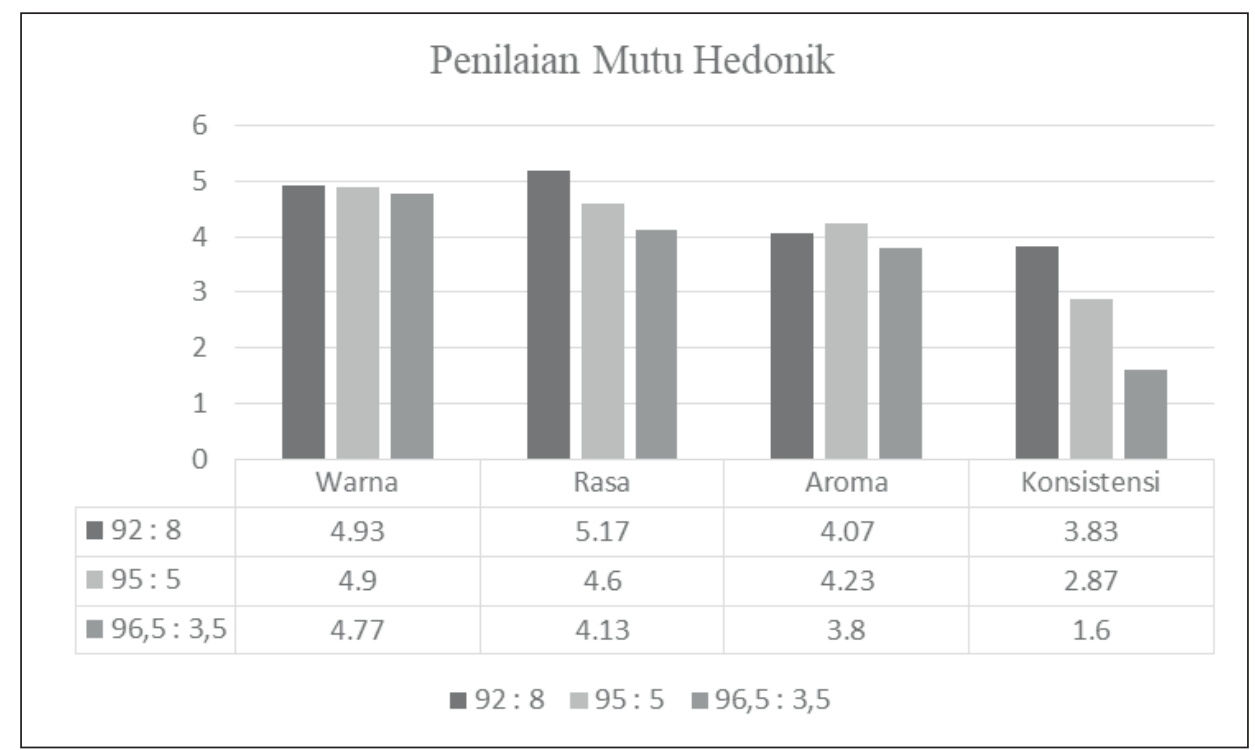

Gambar 1. Penilaian Rata-rata Mutu Hedonik Berdasarkan Kriteria Warna, Aroma, Rasa dan Konsistensi Yoghurt Kacang Komak

penambahan susu skim pada konsentrasi formula yang menyebabkan warna yoghurt kacang komak tidak terlalu banyak berubah (Sintasari, et al., 2014).

Pengujian aroma yang diharapkan pada yoghurt kacang komak ialah beraroma biasa saja (tidak beraroma langu). Hasil rata-rata penilaian uji organoleptik dari 30 panelis menyatakan bahwa substitusi 95:5 memperoleh nilai paling tinggi yaitu 4,23 yang artinya mendekati aroma langu agak ringan. Hasil uji Kruskal Wallis didapat bahwa nilai $\mathrm{p}=0,537(\mathrm{p}>0,05)$, bahwa tidak ada pengaruh substitusi sari kacang komak dan susu skim bubuk terhadap aroma yoghurt kacang komak. Pembuatan sari kacang komak dengan adanya perlakuan perendaman, pengupasan kulit ari dan penggilingan, penambahan air panas, pemanasan dan pemisahan menyebabkan senyawa-senyawa aroma yang kurang enak (langu) mengalami degradasi (Triyono, 2010). Aroma langu yang diujikan ketiga substitusi sudah hilang akibat proses pembuatan sari kacang komak. Ini mendasari bahwa tidak ada pengaruh pemberian susu skim terhadap aroma langu yoghurt kacang komak.

Pengujian rasa yang diharapkan pada yoghurt kacang komak ialah rasa asam. Hasil ratarata penilaian uji organoleptik dari 30 panelis menyatakan bahwa substitusi 92:8 memperoleh nilai paling tinggi yaitu 5,17 yang artinya memiliki rasa asam. Hasil uji Kruskal Wallis didapat bahwa nilai $\mathrm{p}=0,004(\mathrm{p}<0,05)$, maka secara statistik menunjukkan adanya pengaruh substitusi sari kacang komak dan susu skim terhadap rasa yoghurt kacang komak. Uji Mann Whitney dilakukan untuk mengetahui adanya perbedaan diantara masingmasing substitusi. Hasil Uji Mann Whitney dapat disimpulkan terdapat perbedaan rasa antara substitusi 92:8 dengan substitusi 95:5 dengan nilai $\mathrm{p}=0,014(\mathrm{p} 0,05)$ dan antara substitusi 92:8 dengan substitusi 96,5:3,5 dengan nilai $\mathrm{p}=0,003$ ( $\mathrm{p}<0,05$ ), lalu antara substitusi 95:5 dengan substitusi 96,5:3,5 tidak terdapat perbedaan rasa dengan nilai $p=0,253(p>0,05)$. Pengaturan terhadap cita rasa menunjukkan penerimaan konsumen terhadap suatu produk. Rata-rata konsumen Indonesia lebih menerima rasa yang agak asam, sedangkan kriteria yoghurt yang baik adalah yang memiliki rasa yang asam (Askar, et al., 2005). Yoghurt dibuat melalui proses fermentasi menggunakan campuran bakteri Lactobacillus bulgaricus dan Streptococcus thermophillus, yang dapat menguraikan gula susu (laktosa) menjadi asam laktat (Adriani, et al., 2008). Semakin banyak penambahan susu membuat rasa yoghurt memiliki kualitas yang baik yaitu rasa asam yang tepat sesuai yang diharapkan.

Pengujian konsistensi yang diharapkan pada yoghurt kacang komak ialah berkonsistensi kental. Hasil rata-rata penilaian uji organoleptik 
dari 30 panelis menyatakan bahwa substitusi 92:8 memperoleh nilai paling tinggi yaitu 3,83 yang artinya memiliki konsistensi kental. Hasil uji Kruskal Wallis didapat bahwa nilai $\mathrm{p}=0,00$ $(\mathrm{p}<0,05)$, maka secara statistik menunjukkan adanya pengaruh substitusi sari kacang komak dan susu skim terhadap konsistensi yoghurt kacang komak. Uji Mann Whitney dilakukan untuk mengetahui adanya perbedaan diantara masingmasing substitusi. Hasil Uji Mann Whitney dapat disimpulkan terdapat perbedaan kosistensi pada ketiga substitusi yoghurt kacang komak, antara substitusi 92:8 dengan substitusi 95:5 dengan nilai $\mathrm{p}=0,001(\mathrm{p}<0,05)$, antara substitusi 92:8 dengan substitusi 96,5:3,5 dengan nilai $\mathrm{p}=0,000$ $(\mathrm{p}<0,05)$, dan antara substitusi 95:5 dengan substitusi 96,5:3,5 dengan nilai $\mathrm{p}=0,000(\mathrm{p}<0,05)$. Pemberian susu skim yang meningkat akan membentuk konsentrasi yoghurt yang kental dengan terjadinya peningkatan total padatan dan penggumpalan protein yang maksimal (Ariyani, 2013).

\section{Nilai pH Yoghurt Kacang Komak}

Pada gambar 2 terlihat dari ketiga substitusi, $\mathrm{pH}$ yang paling tinggi adalah pada substitusi 96,5:3,5 dan $\mathrm{pH}$ paling rendah pada substitusi 92:8. Yoghurt dibuat melalui proses fermentasi menggunakan campuran bakteri Lactobacillus bulgaricus dan Streptococcus thermophillus, yang dapat menguraikan gula susu (laktosa) menjadi asam laktat. Adanya asam laktat inilah yang menyebabkan yoghurt berasa asam. Semakin

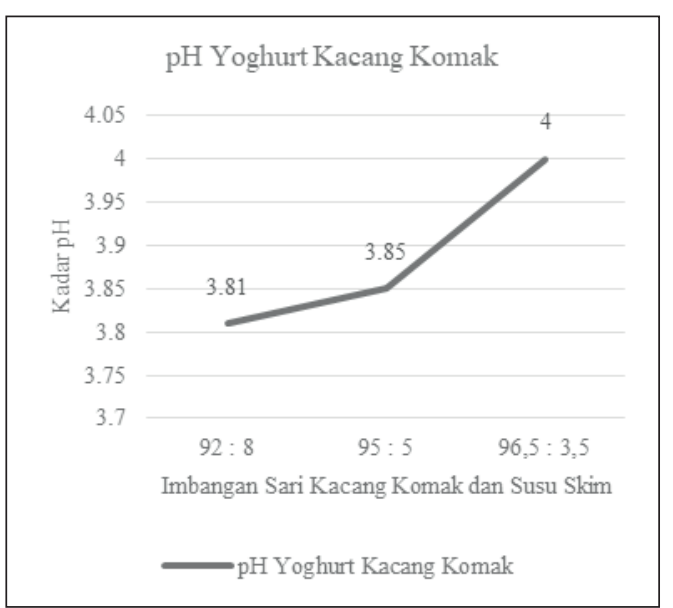

Gambar 2. Grafik pH Yoghurt Kacang Komak meningkat rasa asam yoghurt yang didapatkan maka akan semakin rendah nilai $\mathrm{pH}$, dan begitupun sebaliknya (Hartoto, 2003).

\section{Pengujian Keasaman (Kadar Asam Laktat)}

Berdasarkan kriteria SNI yoghurt mengandung asam laktat sekitar $0,5-2,0 \%$. Rata-rata nilai kadar asam laktat dapat dilihat pada Tabel 1.

Kadar asam laktat yang terkandung dalam yoghurt kacang komak yang didapatkan pada penelitian ini berkisar $0,68-1,02 \%$. Secara keseluruhan kombinasi perlakuan dalam penelitian ini efektif terhadap pembentukan asam laktat dan sesuai dengan nilai $\mathrm{pH}$ yang didapatkan. Peningkatan kadar asam laktat terlihat dengan adanya peningkatan kosentrasi susu skim yang dikombinasikan dengan sari kacang komak. Sesuai dengan hasil penelitian Triyono (2010) penambahan susu skim akan meningkatkan kandungan laktosa yang diikuti dengan meningkatnya jumlah asam laktat yang dihasilkan.

\section{Total BAL Yoghurt Kacang Komak}

Total bakteri asam laktat yang terkandung dalam yoghurt menurut SNI ialah miniman $10^{7}$ $\mathrm{CFU} / \mathrm{ml}$, sedangkan menurut Indratiningsih, et al. (2004), jumlah minimal sel probiotik hidup untuk dapat berperan sebagai agensi pemicu kesehatan adalah $10^{6} \mathrm{CFU} / \mathrm{ml}$. Rata-rata hasil pengujian

Tabel 1. Kadar Asam Laktat Yoghurt Kacang Komak

\begin{tabular}{ll}
\hline Sari Kacang Komak : Susu Skim & Kadar Asam Laktat \\
\hline $92: 8$ & $1,0250 \%$ \\
$95: 5$ & $0,8812 \%$ \\
$96,5: 3,5$ & $0,6852 \%$ \\
\hline
\end{tabular}

Tabel 2. Hasil Perhitungan Jumlah Bakteri Yoghurt (CFU/ $\mathrm{ml})$

\begin{tabular}{ccc}
\hline Substitusi Sari & Pengenceran & Hasil \\
Kacang Komak : & & \\
\cline { 2 - 2 } Susu Skim & $\mathbf{1 0}^{\mathbf{9}}$ & $4,9 \times 10^{11}$ \\
\hline $92: 8$ & 492 & $2,7 \times 10^{11}$ \\
$95: 5$ & 274 & $1,1 \times 10^{11}$ \\
$96,5: 3,5$ & 109 & \\
\hline
\end{tabular}


jumlah total bakteri pada yoghurt lacang komak dapat dilihat Tabel 2.

Hasil penelitian ini menunjukkan bahwa pada tiap substitusi yang dilakukan, yoghurt dalam taraf baik untuk dikonsumsi. Sesuai dengan pengujian sebelumnya yaitu pengujian $\mathrm{pH}$ dan kadar asam laktat, hasil yang didapatkan pada pengujian total bakteri asam laktat sesuai. Semakin menurunnya $\mathrm{pH}$ yoghurt maka semakin meningkat kadar asam laktat dan total bakteri asam laktat yang didapatkan pada yoghurt kacang komak. Terdapat hubungan antara peningkatan kosentrasi susu skim dengan peningkatan total bakteri asam laktat, peningkatan kadar asam laktat dan penurunan nilai $\mathrm{pH}$.

\section{KESIMPULAN DAN SARAN}

Berdasarkan hasil penelitian dapat disimpulkan bahwa substitusi 92:8 lebih mendekati kualitas yoghurt yang diharapkan dari segi sifat organoleptiknya, yaitu rasa, warna dan konsistensi, sedangkan untuk sifat organoleptik aroma substitusi 95:5 lebih mendekati kualitas yoghurt yang diharapkan. Hasil penelitian nilai $\mathrm{pH}$, kadar asam laktat dan total BAL saling mengikuti, yaitu nilai $\mathrm{pH}$ terendah adalah substitusi 92:8 dan tertinggi $96,5: 3,5$, kadar asam laktat dan total BAL tertinggi adalah 92:8 dan teredah 96,5:3,5. Semakin menurunnya $\mathrm{pH}$ yoghurt maka semakin meningkat kadar asam laktat dan total bakteri asam laktat yang didapatkan pada yoghurt kacang komak. Hasil mikroskopis pada perwarnaan Gram didapatkan bahwa terdapat bakteri Streptococcus thermopillus, dan Lactobacillus bulgaricus pada yoghurt kacang komak. Perlu penelitian lebih lanjut untuk mengetahui kadar protein dan antioksidan dalam produk yoghurt kacang komak.

\section{DAFTAR PUSTAKA}

Adriani, L., Indrayati, N., Tanuwira, U.H., \& Mayasari, N. (2008). Aktivitas Lactobacillus acidophilus, dan Bifidobacterium terhadap kualitas yoghurt dan penghambatannya pada Helicobacter pylori. Jurnal Bionatura, 10(2), 129-140. Diakses dari http://jurnal.unpad.ac.id/ bionatura/article/view/7732/3588
Ariyani, P.W. (2013). Viabilitas Lactobacillus acidhopilus dan Bifidobacterium bifidum terenkapsulasi dan mutu sensori yoghurt tepung pisang sinbiotik selama penyimpanan dingin (Skripsi, Institut Pertanian Bogor, Bogor). Diakses dari repository.ipb.ac.id/jspui/ bitstream/123456789/63802/1/F13pwa.pdf

Askar, Surayah, \& Sugiarto. (2005). Uji kimiawi dan organoleptik sebagai uji mutu yoghurt. Bogor: Balai Penelitian Ternak dan Pasca Panen Pertanian.

Bangun, R.S. (2009). Pengaruh fermentasi bakteri asam laktat terhadap kadar protein susu kedelai (Skripsi yang tidak dipublikasikan), Universitas Negeri Semarang, Semarang. Diakses dari: http://lib.unnes.ac.id/1234/

Dewan Standarisasi Nasional. (2009). SNI yogurt (SNI 2981:2009). Jakarta: Dewan Standarisasi Nasional.

Hartoto, M. (2003). Pembuatan yoghurt sinbiotik dengan menggunakan kultur campuran: streptococcus thermophilus, bifidobacterium bifidum, dan lactobacillus casei galur shirota (Skripsi yang tidak dipublikasikan), Institut Pertanian Bogor, Bogor. Diakses dari: http:// repository.ipb. ac.id/handle/123456789/21758

Hartoyo, A., Muchtadi, D., Astawan, M., Dahrulsyah, \& Winarto A. (2011). Pengaruh ekstrak protein kacang komak (Lablab purpureus (L.) Sweet) pada kadar glukosa darah dan profil lipida serum tikus diabetes. Jurnal Teknologi dan Industri Pangan, 22(1), 58-63. Diakses dari: http://journal.ipb. ac.id/index.php/jtip/article/ view/3397

Indratiningsih, Widodo, Siti, \& W. Endang. (2004). Produk yoghurt shiitake sebagai pangan kesehatan berbasis susu. Jurnal Teknologi dan Industri Pangan, 25(1), 54-60. Diakses dari: http://repository.ipb.ac.id/bitstream/ handle/123456789/29833/Indratiningsih ProduksiYoghurt_2004_N01_\%2054-60.pdf; jsessionid=E87476EBB87B3BE7A6FF9B4D 20808F7D?sequence $=1$

Jannah, A.M., Legowo A.M., Pramono Y.B., AlBarri A.N., \& Abduh B.M. (2014). Total bakteri asam laktat, ph, keasaman, citarasa dan kesukaan yogurt drink dengan penambahan ekstrak buah belimbing. Jurnal aplikasi teknologi pangan, 3(2), 7-11. Diakses dari: http://journal.ift.or.id/ files $/ 310711 \% 20$ total $\% 20$ bakteri $\% 20$ asam $\% 20$ 
laktat, $\% 20 \mathrm{ph}, \% 20$ keasaman, $\% 20$ citarasa $\% 20$ dan $\% 20$ kesukaan\%20yogurt\%20drink\%20 dengan $\% 20$ penambahan $\% 20$ ekstrak $\% 20$ buah\%20belimbing_0.pdf

Kumalasari, K.E.D., Legowo A.M., \& Al-Baarri A.M. (2013). Total bakteri asam laktat, kadar laktosa, ph, keasaman, kesukaan drink yogurt dengan penambahan ekstrak buah kelengkeng. Jurnal Aplikasi Teknologi Pangan, 2(4), 165168. Diakses dari: http://jatp.ift.or.id/index.php/ jatp/article/view/164

Nizori, A., Suwita, V., Surhaini, Mursalin, Melisa, Sunarti T.C., \& Warsiki, E. (2008). Pembuatan soyghurt sinbiotik sebagai makanan fungsional dengan penambahan kultur campuran Streptococcus thermpohillus, Lactobacillus bulgaricus, dan Lactobacillus achidophilus. Jurnal Teknologi Industri Pertanian, 18(1), 2833. Diakses dari: http://journal.ipb.ac.id/index. php/jurnaltin/article/view/4203/2854

Ratnaningtyas, A. (2003). Tahu dari kacang non kedelai; studi kasus kacang komak (Skripsi, Institut Pertanian Bogor, Bogor). Diakses dari: http://repository.ipb.ac.id/ handle/123456789/17699

Sintasari, R.A., Kusnadi, K., \& Ningtyas, D.W. (2014). Karakteristik minuman probiotik sari beras merah. Jurnal Pangan dan Argoindustri, 2(3), 65-75. Diakses dari: http://jpa.ub.ac.id/ index.php/jpa/article/download/53/63
Suharjanto, T. (2010). Respon hasil kacang komak terhadap intensitas cekaman kekeringan. Agrika, 4(1), 30-36. Diakses dari: http://publishingwidyagama.ac.id/ejournal-v2/index.php/agrika/ article/view/146

Surajudin, Fauzi, R.K., \& Dwi, P. (2008). Yoghurt susu fermentasi yang menyehatkan. Jakarta: Agromedia Pustaka.

Triyono, A. (2010). Mempelajari pengaruh meltodekstrin dan susu skim terhadap karakteristik yoghurt kacang hijau. Subang: Balai Besar Pengembangan Teknologi Tepat Guna - LIPI.

Winarno, F.G. (2002). Kimia pangan dan gizi. Jakarta: PT. Gramedia Pustaka Utama.

Winarti, S., Mardiana N.R., Hackiki, R., Setiyoningrum, P., \& Novitri, D. (2010). Pembuatan yoghurt sinbiotik berbahan dasar susu kacang komak (Lablab purpureus (l.) Sweet) dan ekstrakubi jalar putih dengan menggunakan kultur campuran Lactobacillus delbrueckii subsp. bulgaricus, Streptococcus salivarius Subsp. thermophilus, dan Bifidobacterium bifidum. (Laporan Akhir PKMP yang tidak dipublikasikan), Institut Pertanian Bogor, Bogor. Diakses dari: http://repository.ipb. ac.id/ jspui/bitstream/123456789/44493/4/ laporan\%20akhir\%20pkmp\%20yoghurt\%20 kacang\%20komak\%20(1).doc 